Marian Nowak*

Lublin

\title{
Przebaczenie w wychowaniu
}

Chrześcijaństwo zaleca człowiekowi wybaczać krzywdy. Lecz dlaczego tak czyni? Dlaczego przebaczanie było tak ważne w nauczaniu Jezusa Chrystusa? Te zwykłe pytania pozwalają nam podjąć problem, który wydaje się być istotny również dla wychowania i pedagogiki. Podejmuję zatem zagadnienie przebaczenia $\mathrm{w}$ wychowaniu ze szczególnym odniesieniem się do uwarunkowań życia człowieka wierzącego, od najmłodszych lat stykającego się z tym tematem, lecz zbyt często pozostawionego samemu sobie wobec nieuniknionych trudności w rozumieniu przebaczenia jako wartości oraz częstej niemożności wprowadzenia w praktykę tego, co każe mu czynić Ewangelia.

Co rozumiemy, gdy wypowiadamy słowo ,przebaczenie”? Z jednej strony wydaje się być ono kategorią ujmującą fakt najbardziej ludzki i świadczący o wielkości samego człowieczeństwa, a z drugiej strony jest ono też postrzegane i odczytywane jako przejaw słabości i braku odwagi. Już te odcienie rozumienia kategorii „przebaczenie” wskazują, że jej zdefiniowanie nie jest rzeczą łatwą.

Intuicyjnie i na ogół poprawnie rozumiemy oraz przeżywamy treść pojęcia „przebaczenie”, ale powstają trudności z wyrażeniem tej rzeczywistości słowami i opisaniem jej - jak zresztą ma to miejsce z każdą sytuacją

* Ks. prof. dr hab. Marian Nowak jest kierownikiem Katedry Pedagogiki Ogólnej w Instytucie Pedagogiki Katolickiego Uniwersytetu Lubelskiego Jana Pawła II. Adres: Instytut Pedagogiki KUL, ul. Droga Męczenników Majdanka 70, 20-325 Lublin; e-mail: marian. nowak@kul.pl. 
i faktem, który przeżywamy dogłębnie jako ludzie. Ujęcia tego zjawiska zmierzają do naświetlenia jego aspektów psychologicznych, społecznych czy środowiskowych, czasami także filozoficznych i teologicznych.

Nie brakuje podejść ujmujących ten fakt dokonany, jednorazowy, jako przejaw nadzwyczajnego i rzadko spotykanego przeżycia, ale też znajdziemy wiele ujęć procesualnych, wskazujących na zachodzenie tego zjawiska $\mathrm{w}$ pewnym przedziale czasowym, w którym przebaczenie miałoby być na końcu tego procesu - jego zwieńczeniem, a nie nim samym.

\section{Fakt przebaczenia i jego interpretacje w perspektywie etymologicznej i antropologicznej}

Etymologicznie słowo „przebaczenie” wiąże się z przedrostkiem „prze-”, wskazującym na pewien stan już dokonany i oznacza zwiększoną, a nawet pełną intensywność czegoś, a w związku z ,przebaczeniem”- pełne darowanie czegoś, o czym możemy stwierdzić następnie, że jest dane tej osobie lub grupie, jako ponowne „baczenie”, czyli odpowiedni respekt i uwaga, związane $\mathrm{z}$ całkowitym zaniechaniem odpłaty, zemsty czy gniewu ${ }^{1}$.

Przebaczenie wydaje się być faktem dość obcym naszym czasom, naznaczonym zawiścią, akcjami terroryzmu i legalizmem. Ale i w tych okolicznościach nie brakuje tęsknoty ludzkości za czymś więcej, za doskonalszą rzeczywistością, jak to wyrażał napis niesiony podczas jednej z manifestacji pokojowych, który brzmiał: „Zatrzymując się na zasadzie oko za oko, narażamy się wszyscy na zagrożenie pozostawania ślepymi”’2.

Głód lepszej przyszłości i humanizowania naszej ziemi oraz czynienie jej przyjazną naszej egzystencji, zauważane między innymi przez Gabriela Marcela (1889-1973), wskazują na prawdziwą potrzebę czynienia wszystkiego, co możliwe, aby człowiek nie utracił nadziei, czyli wiary w osiągnięcie dobra, które spełni go jako istotę indywidualną i społeczną3.

Wolność i prawa człowieka, poszanowanie życia, dążenie do powiązania równości ze sprawiedliwością, dążenie do zaprowadzania politycznego

${ }^{1}$ Mały słownikjęzyka polskiego, red. Stanisław Skorupka, Halina Auderska, Zofia Łempicka (Warszawa: PWN, 1969), 638.

2 Zob. Carlo Nanni, Educare cristianamente. Lettere spirituali a educatori, insegnanti e formatori (Leumann-Torino: Elledici, 2008), 145.

3 Zob. Gabriel Marcel, Homo viator (Roma: Borla, 1980), 160 n.; Andrzej Maryniarczyk, „Homo Viator”, Człowiek w Kulturze 23 (2013): 29-35. 
systemu coraz bardziej demokratycznego - to konkretne przejawy stałego zaangażowania pojedynczych ludzi i całej ludzkości na rzecz lepszego człowieczeństwa dla każdego pojedynczego człowieka i dla całych społeczności.

Jednym z wyrazów tych dążeń i objawieniem lepszego człowieczeństwa jest przebaczenie. Wiąże się ono z miłosierną odpowiedzią w odniesieniu do osoby lub grupy, popełniających zło wobec nas lub grupy. W akcie przebaczenia osoba przebaczająca zamienia uczucia nienawiści, gniewu lub urazu, także swoje surowe osądy i zachowania związane z zemstą lub dążeniem do odwetu wobec winowajcy, zwykle bardziej lub mniej uzasadnione - na uczucia i osądy pozytywne, związane z respektem, akceptacją, dążeniem do zrozumienia i z wyrozumiałością, które dominują nad doznaną krzywdą lub niesprawiedliwością ${ }^{4}$.

Tak definiowane przebaczenie odróżnia się od sprawiedliwości przez fakt, że jest ono darowane jako bezwarunkowe i niekoniecznie odwzajemnione przez osobę, która nawet może nie zasługiwać na nie. W tym znaczeniu przebaczenie nie znosi niesprawiedliwości ani o niej nie zapomina, lecz zaprzestaje oceniania osoby w kategoriach tego, co zrobiła. Nie jest ono zatem ani brakiem odwagi i siły, ani przejawem jakiejś moralnej słabości, lecz wymaga szczególnej odwagi i moralnej siły 5 .

Jak łatwo możemy zauważyć, przebaczenie nie jest jakimś zjawiskiem spontanicznym czy instynktownym, lecz wiąże się z pewnym aktem dokonującym się między ludźmi w pewnym okresie czasu - jest ono pewnym procesem. Wychodząc od tego ujęcia, zauważamy, że odkrywana jest tutaj całkowicie inna droga niż droga sprawiedliwości, rozumianej zgodnie ze słowami tradycyjnej zasady prawa obowiązującego między innymi w starożytności: „Oko za oko, ząb za ząb” - a rozumiana jako wyrównanie rachunków w relacjach z innymi ${ }^{6}$.

Możemy też usiłować rekonstruować drogę rozwoju ludzkości i jej dojrzewania do rozumienia idei przebaczenia: na początkowym etapie jej rozwoju należy wymienić egzekwowanie sprawiedliwości przez rodzinę i bliskich, polegające na dążeniu do wyrównywania rachunków w relacjach międzyludzkich, a co zwykle egzekwowali wobec winowajców najbliżsi i rodzina poszkodowanego; następnie w wyniku jednak niezadowolenia z takiego stanu rzeczy zauważamy dążenie do większego obiektywizowania

${ }^{4}$ Zob. Jacques Schepens, „Perdono”, w: Dizionario di scienze dell'educazione, red. José M. Prellezo, Guglielmo Malizia, Carlo Nanni (Torino: ElleDiCi - SEI, 1997), 812-813.

5 Tamże, 812.

${ }^{6}$ Por. Nanni, Educare, 145. 
zasady sprawiedliwości przez powierzanie jej egzekwowania odpowiednim organom sprawiedliwości i procesowi sądowemu; wreszcie dochodzimy do zrozumienia idei przebaczenia, wniesionej i ugruntowywanej zwłaszcza przez nauczanie Jezusa Chrystusa, który wyraża swoje całkowicie nowe stanowisko wobec etyki Starego Testamentu i wobec etyki ogólnoludzkiej. Jest to nie tylko, jak zauważa Romano Guardini, przedstawienie nowej etyki, ale w ogóle proklamacja nowego etosu?

Przebaczenie jest zatem zjawiskiem o pochodzeniu religijnym, które staje się obecne najpierw w tradycyjnych systemach wychowawczych, zwłaszcza w chrześcijaństwie, w którym znajduje ono swoje szczególne umocowanie $\mathrm{w}$ fakcie przebaczenia ludzkości wyjednanego u Boga przez Jezusa Chrystusa. W nauczaniu Jezusa, w Kazaniu na Górze, mamy swoistą proklamację tej właśnie nowej hierarchii wartości i nowego ładu życia społecznego, nowej mentalności moralnej, pozostającej co prawda w relacji do Dekalogu, ale z nową jej interpretacją, związaną nade wszystko z przebaczeniem.

Umownie możemy też stwierdzić, że o ile etos Starego Przymierza zalecał nieczynienie więcej niż mi uczyniono, według Chrystusa to nie wystarcza. Pozostawanie w sferze sprawiedliwego ekwiwalentu nie wyprowadza bowiem z kręgu niesprawiedliwości. Wyrównawcze działania zawsze mają problem z przebraniem miary i w rezultacie kończą się dopuszczaniem się niesprawiedliwości.

Tak zatem przebaczenie należy wiązać z Nowym Testamentem i nauczaniem samego Chrystusa wyrażonym zwłaszcza w orędziu Ośmiu błogosławieństw, a następnie $\mathrm{w}$ wielokrotnych wskazaniach na temat nowego stylu życia uczniów Chrystusa, jakie znajdujemy w Ewangeliach.

Dopiero z czasem, zwłaszcza na gruncie nauk społecznych, zaczęto odkrywać wartość terapeutyczną, uzdrawiającą i edukacyjną przebaczenia, zauważając jego aspekty pozytywne: wzmocnienie poczucia własnej wartości, zdolności relacji, nadzieja na przyszłość, redukcja niepokoju. Te wszystkie - odkrywane na gruncie nauk społecznych - wartości przebaczenia doprowadziły do zainteresowania się tym zjawiskiem także przez nauki humanistyczne, filozofię i teologię, podkreślając jego wartość także na gruncie pedagogiki.

Sięgnijmy zatem najpierw po inspirację czerpaną z teologii biblijnej, by lepiej zrozumieć sam fakt przebaczenia - wyjaśniany i praktykowany

${ }^{7}$ Romano Guardini, Bóg. Nasz Pan Jezus Chrystus - Osoba i życie, thum. Juliusz Zychowicz (Warszawa: Apostolicum, 1999), 81. 
w chrześcijańskiej tradycji jego przeżywania i interpretowania, także z bezpośrednimi odniesieniami do procesu wychowania pojedynczego człowieka i całych grup społecznych.

Przebaczenie rozumiane i interpretowane w świetle nauczania Chrystusa różni się od wcześniejszych poszukiwań sprawiedliwości proporcjonalnej, a także od współczucia oraz od miłosierdzia, chociaż może się z nimi wiązać i zawierać niektóre ich elementy lub cechy. W ramach tych rozróżnień warto przywołać interpretację miłosierdzia wskazaną między innymi przez papieża Franciszka, według którego jest ono w gruncie rzeczy boskie i jest ono związane z sądem nad naszym grzechem. Z kolei współczucie ma bardziej ludzkie oblicze i oznacza „współ-czucie”, czyli współodczuwanie, wspólnotę w odczuwaniu, a także wspólne odczuwanie, niepozostawanie obojętnym na ból i cierpienie innych. Odczuwał je na przykład Jezus widząc thumy, które szły za Nim. Podobnie, gdy wzruszył się, widząc łzy matki młodzieńca z Nain. Jest to czucie z innymi (współczucie) płynące jakby z głębi nas samych ${ }^{8}$.

Rzeczywistość przebaczenia najwydatniej zaznaczona została, a następnie jest dzisiaj przywoływana wśród chrześcijan, w przedostatniej prośbie modlitwy Ojcze nasz, gdy mówimy: „Przebacz nam nasze winy, jak i my przebaczamy tym, którzy przeciw nam zawinili" (Mt 6, 12). W Ewangelii Marka mamy kontynuację tego wątku: „A kiedy stajecie do modlitwy, przebaczcie, jeśli macie co przeciw komu, aby także Ojciec wasz, który jest w niebie, przebaczył wam wykroczenia wasze" (Mk 11, 25).

Nawiązując do Modlitwy Pańskiej, Mateusz odnotowuje: „Jeśli bowiem przebaczycie ludziom ich przewinienia, i wam przebaczy Ojciec wasz niebieski. Lecz jeśli nie przebaczycie ludziom, i Ojciec wasz nie przebaczy wam waszych przewinień" (Mt 6,14n).

Przebaczenie naszych grzechów przez Boga jest jak najściślej związane z przebaczeniem, jakiego my sami udzielamy lub odmawiamy naszemu bliźniemu z tytułu uczynionej nam krzywdy. Powstaje jednak pytanie o możliwą

${ }^{8}$ Takie rozróżnienie znajdziemy we fragmencie rozmowy papieża Franciszka z Andreą Torniellim, gdzie czytamy m.in.: „Miłosierdzie jest boskie, jest bardziej związane z sądem nad naszym grzechem. Współczucie ma bardziej ludzkie oblicze. Oznacza wspólne odczuwanie, niepozostawanie obojętnym na ból i cierpienie innych. To właśnie czuł Jezus, kiedy widział tłumy, które za Nim szły. Zabrał apostołów w pustynne miejsce, jak pisze w swojej Ewangelii Marek. Tłum widział, jak wyruszają w swojej łodzi, zrozumiał, dokąd się kierują i udał się tam pieszo, wyprzedzając ich. Jezus wyszedł z łodzi i «ujrzał wielki tłum. Zlitował się nad nimi, byli bowiem jak owce niemające pasterza. I zaczął ich nauczać o wielu sprawach» $(6,34)$ ”. (Franciszek, Miłosierdzie to imię Boga (Kraków: Znak, 2015)). 
czy wskazaną jakąś optymalną ilość tych naszych „przebaczeń”, jak pytał Piotr: „Panie, ile razy mam przebaczyć, jeśli mój brat wykroczy przeciwko mnie? Czy aż siedem razy?” Jezus mu odrzekł: „Nie mówię ci, że aż siedem razy, lecz aż siedemdziesiąt siedem razy" (Mt 18, 21n).

Już tych kilka odniesień do teologii biblijnej pozwala nam zauważyć, że przebaczenie to nie jest coś przygodnego, sporadycznego, tym bardziej naturalnego, lecz jest to pewien trwały element egzystencji wykraczającej poza wymiar natury - transcendującej ku Bogu i dopiero w tym kontekście jest ono nieustannie aktualizowaną postawą jednego człowieka wobec drugiego.

Zresztą wydaje się, że aby uświadomić jeszcze wyraźniej tę rzecz swoim słuchaczom, sam Jezus opowiada przypowieść o królu, który rozlicza się ze swoimi sługami: z ksiąg rachunkowych wynika, że jeden ze sług jest mu winien ogromną sumę pieniędzy i rozkazuje go sprzedać wraz z jego mieniem, aby pokryć należność. Gdy człowiek ten błaga o litość, jego pan daruje mu dług. Gdy ułaskawiony, wracając do domu, spotkał innego sługę, który był mu winien o wiele mniejszą sumę niż jego poprzedni dług, napada na niego i stosuje $\mathrm{z}$ całą bezwzględnością wobec niego prawo praktykowane wobec dłużników. W tym drugim przypadku zabrakło wyraźnie odniesienia się do wymiaru transcendencji i pamięci o większym długu darowanym wcześniej. Słysząc o takim zdarzeniu, król z przypowieści wpada w gniew i postępuje już teraz wobec swojego dłużnika tak samo, jak postąpił jego dłużnik wobec swojego dłużnika. Konkluzja zaś jest taka: „Podobnie uczyni wam Ojciec mój niebieski, jeżeli każdy z was nie przebaczy z serca swemu bratu" (Mt 18, 35).

W perspektywie chrześcijańskiej znajdujemy jeszcze dalej idące analizy faktu przebaczenia, a mianowicie: jeśli ktoś wyrządził nam krzywdę i przyznaje się, wybaczamy mu, ale co robić, jeśli ten, kto wyrządził nam krzywdę, nie widzi tego i nie chce się przyznać? Według nauczania Jezusa powinniśmy również i o niego zatroszczyć się. Uczynionej krzywdy nie możemy traktować jako okazji do przeżywania i manifestowania swojej moralnej wyższości, lecz należy widzieć tu okazję do dążenia, by człowiek wyrządzający taką krzywdę zrozumiał swój błąd i naprawił go. Jeśli chcemy spełnić to, czego żąda Chrystus, musimy najpierw przezwyciężyć odpowiedź własnego serca na doznaną krzywdę - złość i chęć wyegzekwowania swego prawa - aby stać się prawdziwie wolnym.

Dopiero kiedy do gruntu przebaczysz i dojdziesz do porozumienia z prawdziwym ,ja" drugiego człowieka, stworzysz warunki, by drugi zaczął cię słuchać. Jeśli tak uczynisz, ,pozyskasz swego brata” (Mt 18, 15). 


\section{Możliwość popełnienia błędu przez człowieka i konieczność otrzymania przebaczenia}

Przebaczenie może dotyczyć nas samych, naszej relacji z Bogiem i ze światem. Zanim wskażemy na podstawowe ujęcia i interpretacje przebaczenia, a następnie na jego edukacyjną wartość i implikacje dla wychowania, sięgnijmy po wybrane przykłady bardzo wartościowych i głębokich opisów sytuacji oraz procesu przebaczenia, jakie znajdujemy w twórczości Henryka Sienkiewicza (1846-1916), którego przywołamy z racji przeżywanego roku Sienkiewiczowskiego w naszej Ojczyźnie, odwołując się między innymi do powieści: Quo Vadis i Krzyżacy. Wydaje się też, że właśnie ten pisarz zdołał oddać złożoność rzeczywistości przebaczenia, także jego procesualność i dynamikę - z wyraźnym też inspirowaniem się chrześcijańskim jego rozumieniem:

1) Pierwszy opis dotyczy znanego zawołania: „Glauku przebacz!”. To zawołanie i opis należą do najbardziej poruszających stronic Quo vadis, za którą Sienkiewicz otrzymał nagrodę Nobla w 1905 roku. Stanowią element historii spotkania Chilona, dopuszczającego się wielu czynów niegodziwych wobec chrześcijan i wielokrotnie doznającego od nich przebaczenia oraz Glauka, chrześcijańskiego lekarza, ze wskazania Chilona przywiązanego w ogrodach Cezara do słupa, na którym pochłaniają go płomienie. W opisie Sienkiewiczowskim tak odzwierciedlony jest sam moment przebaczenia:

Twarz miał zbolałą i pochyloną, jakby chciał po raz ostatni przypatrzeć się swemu katowi, który go zdradził; pozbawił go żony, dzieci, nasadził na niego zabójcę, a gdy to wszystko zostało mu w imię Chrystusa odpuszczone, raz jeszcze wydał go w ręce oprawców. Nigdy człowiek nie wyrządził człowiekowi straszniejszych i bardziej krwawych krzywd. I oto ofiara płonęła teraz na smolnym słupie, a kat stał u jej stóp. Oczy Glauka nie odwracały się od twarzy Greka. Chwilami przesłaniał je dym, lecz gdy dmuchnął powiew, Chilo widział znów te utkwione w siebie źrenice. [...] Nagle zachwiał się i wyciągnąwszy w górę ramiona zawołał okropnym, rozdzierającym głosem: - Glauku! W imię Chrystusa! Przebacz! Uciszyło się naokół: dreszcz przebiegł obecnych i wszystkie oczy mimo woli podniosły się w górę. A głowa męczennika poruszyła się lekko, po czym usłyszano z wierzchołka masztu podobny do jęku głos: - Przebaczam!...?.

\footnotetext{
${ }^{9}$ Henryk Sienkiewicz, Quo vadis (Warszawa: PIW, 1961), 589-590.
} 
2) Druga sytuacja, którą chcę przywołać, dotyczy postaci Juranda ze Spychowa - rycerza i ojca rodziny. Jurand ze Spychowa to jedna z głównych postaci powieści Sienkiewicza pod tytułem Krzyżacy. Jako mężny rycerz mazowiecki, a także kochający mąż i oddany ojciec, po stracie swojej żony, która zmarła podczas ataku krzyżaków na Złotoryję, najpierw odnajduje sens życia w straszliwej zemście. Jako rycerz odważny i zawzięty, nie znał on litości dla krzyżaków. Dzięki swojej odwadze i przebiegłości wychodzi zwycięsko ze wszystkich potyczek. Jego imię budzi podziw wśród Polaków, a strach pośród krzyżaków. Jako dobry ojciec, bardzo kochał on swoją córkę, Danusię. A kiedy ona została porwana przez krzyżaków, Jurand dla jej ratowania poświęca wszystko, nie tylko własne bezpieczeństwo, ale i rycerską dumę i godność. Dla swej córki jest w stanie znieść najgorsze upokorzenie, którego doznaje w zamku krzyżackim w Szczytnie. Z zamku w Szczytnie wyszedł jako niewidomy starzec, bez prawej ręki i języka, z białymi opadającymi na ramiona włosami i brodą do pasa. Mimo że bardzo przeżył śmierć swojej córki, pogodził się ze swoim losem. Wyrzekł się zemsty, a sprawiedliwości szukał u Boga. Przebacza on Zygfrydowi De Löwe - sprawcy swoich krzywd. Jego czyn budzi podziw i szacunek. Świadczy o wielkiej przemianie, jaka dokonała się w tym twardym człowieku. Udało mu się przełamać własną nienawiść i poczucie krzywdy. Jest to postać bardzo wartościowa, która budzi współczucie, podziw oraz sympatię.

Biorąc pod uwagę oba opisy i ujmując je fenomenologicznie, możemy zauważyć, że w przypadku pierwszym - Glauka, przebaczenie jest faktem w konkretnej sytuacji i raczej niespodziewanym, podyktowanym wiarą w Jezusa Chrystusa, a w prośbie Greka o przebaczenie, ufności związanej z dostrzeżeniem tej nowości będącej wypadkową przyjęcia Jego nauczania przez pierwszych chrześcijan. W drugim przypadku możemy mówić o procesie dojrzewania Juranda do przebaczenia, którego postawa najpierw przejawia dążenie do zemsty i mściwości, ale opisane wyżej doświadczenia uruchamiają proces dojrzewania tego człowieka do przebaczenia. Jest to już opis wyraźnie procesualny.

Wiele podobnych sytuacji znajdujemy zwłaszcza w trylogii Sienkiewicza, jak to widzimy chociażby w Potopie i sytuacji rehabilitacji społecznej Kmicica w oczach Oleńki Bilewiczówny oraz całej lokalnej społeczności. Nawiasem mówiąc, warto zwrócić uwagę na ten wymiar w twórczości Henryka Sienkiewicza, jako na zaniedbaną perspektywę interpretacyjną i niewykorzystany wielki potencjał edukacyjny. Częste określenia jego twórczości jako „ku pokrzepieniu serc”, a nawet jako podtrzymywanie megalomanii 
narodowej, można ujmować z całkowicie innej perspektywy, gdy jako jedną z dominujących wartości wyróżnimy przebaczenie. Opisując czasy potęgi Polski, jak również przychodzące okresy klęski, Sienkiewicz potrafił opisywać i wychowywać do wspaniałomyślności, a także ugruntowywać wartość przebaczenia jako ważnej cechy, która wraz z chrześcijaństwem zagościła w polskiej kulturze i w naszej rzeczywistości życia.

Przywołane wyżej opisy pochodzą wprawdzie z powieści, lecz nie odbiegają od podobnych do tych sytuacji z gestami miłości wśród ludzi obdarzonych nadzwyczajnymi nadnaturalnymi przymiotami. Ludzi tych możemy podziwiać i brać z nich wzór. Przywołane przykłady mogą też rodzić pedagogiczną refleksję na temat możliwości wspierania naszych wychowanków, a również wychowywania $w$ nas samych tego rodzaju postawy budzącej najwyższy szacunek w świecie ludzkim. A chociaż przywołane przykłady odnoszą się do dość odległej przeszłości, to jednak nie wydają się być pozbawione swojej aktualności we współczesnym wychowaniu.

Jak zawsze, również i dzisiaj potrzebujemy przebaczenia nie tylko w sytuacjach wyjątkowych, lecz także w ramach życia codziennego, w którym nie brakuje (z naszej winy) rozczarowań i zawodów w kontaktach z innymi. Rozwiązaniem powstających wówczas napięć i problemów jest przebaczenie, które opiera się też na niezbitym fakcie antropologicznym, wyrażanym w maksymie: errare humanum est ('bładzenie jest rzecza ludzka'). Dopuszczenie możliwości popełnienia błędu przez człowieka oznacza także przyzwolenie, aby drugi (doświadczający konsekwencji tego błędu) mógł przebaczyć i dostąpić przebaczenia. Taka sytuacja, wskazując na przebaczenie, jako na zjawisko wpisane w ludzką kondycję, a zatem jako na fakt antropologiczny, może być - a nawet powinna być - jednym z istotnych zadań wychowania i nauczania.

\section{Wychowywanie do przebaczania}

Jak jednak realizować tę drogę odkrywania wartości przebaczenia i następnie wychowywania (także siebie samego) do przebaczania? Wydaje się być ważne, jak też najbardziej pomocne w tej realizacji (z racji wyżej wymienionych), autentyczne wejście w Jezusową naukę o przebaczeniu, do głębi przez Niego zrealizowaną i przyjętą jako podstawowy element Jego życiowej doktryny. Następnie możemy też pytać, co możemy z naszej strony uczynić, aby ten proces uczynić skutecznym w nas samych? Takie pytanie 
postawił sobie kiedyś Romano Guardini w swoim dziele Der Herr (przetłumaczonym na język polski jako: Bóg. Nasz Pan Jezus Chrystus. Osoba $i \dot{z} y c i e)^{10}$, wychodząc od poszukiwania odpowiedzi na następujące pytania:

1) Co człowiek musi w sobie przezwyciężyć, aby rzeczywiście móc przebaczyć?

Odpowiadając na powyższe pytanie, Guardini zachęca do przyjęcia pewnego procesu, zaczynającego się od warstwy najniższej - biologicznej. Najpierw bowiem w naturalnej sferze istnienia należy przezwyciężyć poczucie, że mamy do czynienia z nieprzyjacielem. Jest to poczucie obecne także w świecie zwierząt. Istoty żyjące obok siebie doświadczają, że utrzymanie się przy życiu jednej zagraża życiu drugiej. Człowiek przez grzech wpędzony również w tę kondycję walki o byt doświadcza wszystkiego podobnie. Ktoś, kto mi wyrządził krzywdę, jest moim wrogiem. Budzi we mnie uczucie nieufności, lęku, odrazy, a w konsekwencji - dążąc do zachowań obronnych wobec niego - mam się na baczności, instynktownie mu niedowierzam i przybieram postawę gotowości na obronę w przypadku ataku $\mathrm{z}$ jego strony ${ }^{11}$.

Tutaj pojawia się zatem pierwszy wymóg i zarazem warunek przebaczenia - rezygnacja ze zrozumiałej oraz naturalnej nienawiści czy niechęci jako postawy obronnej. Chodzi o przezwyciężenie swojego lęku, o zdobycie się na odwagę, aby stanąć naprzeciwko drugiego z silnym poczuciem, że ów nieprzyjaciel nie jest w stanie zagrozić temu, co we mnie najistotniejsze - mojemu człowieczeństwu. Owszem, należy zachować roztropność i nie mieć złudzeń co do tego, kto chce mi wyrządzić krzywdę, ale tu chodzi o coś głębszego - właśnie o przebaczenie.

Przebaczenie wymaga natomiast rzeczywiście ogromnej wewnętrznej odwagi, wypływającej z wewnętrznego poczucia bezpieczeństwa. Jest to, zdaniem Guardiniego, postawa ze wszech miar słuszna, gdyż ten, kto autentycznie przebacza, jest wewnętrznie silniejszy od tego, który się lęka i nienawidzi ${ }^{12}$.

Znamy dość dobrze takie właśnie stwierdzenia z nauczania i wypowiedzi ks. Jerzego Popiełuszki, gdzie jeden z fragmentów wprost zawiera słowa: „Nie walcz przemocą. Przemoc nie jest oznaką siły, lecz słabości. Komu nie udało się zwyciężyć sercem lub rozumem, usiłuje zwyciężyć przemocą". Konkretnie z dnia 26 grudnia 1982 roku pochodzi wypowiedź ks. Jerzego

\footnotetext{
${ }^{10}$ Guardini, Bóg, 290 n.

11 Zob. tamże, 295.

12 Zob. tamże.
} 
Popiełuszki wyrażona w kazaniu na ten temat: „Każdy przejaw przemocy dowodzi moralnej niższości. Najwspanialsze i najtrwalsze walki, jakie zna ludzkość, jakie zna historia, to walki ludzkiej myśli. Najnędzniejsze i najkrótsze to walki przemocy. Idea, która potrzebuje broni, by się utrzymać, sama obumiera. Idea, która utrzymuje się tylko przy użyciu przemocy, jest wypaczona. Idea, która jest zdolna do życia, podbija sobą" ${ }^{13}$.

2) Dlaczego przebaczać? Dlaczego nie realizować sprawiedliwości?

W poszukiwaniu odpowiedzi na to pytanie Romano Guardini wskazuje na społeczną naturę człowieka i na społeczny kontekst naszego życia, przejawiający się we wspólnym losie nas wszystkich, wymagającym tego, co określa jako „rozluźnienie serca”14.

Istnieje też pewna strona negatywna tego faktu, która przeszkadza nam w przebaczeniu: chodzi o trudności, jakie napotykamy w procesie przebaczania, mechanizmy obronne, które uruchamiają się i w konsekwencji uniemożliwiają, zwłaszcza wierzącemu człowiekowi, otwarcie się na ten gest i przeżycie właściwe tego faktu. W naszej codzienności skupiamy uwagę najczęściej na jakimś jednym elemencie czy aspekcie, a tymczasem wydaje się być tutaj konieczne zestawienie razem różnych momentów jednego procesu: przebaczyć innym - przebaczyć sobie samemu - dostąpić przebaczenia od Boga. Jeśli przebaczenie, jak często to faktycznie ma miejsce, będzie analizowane w sposób cząstkowy, oddzielający osobę przebaczającą od osoby, której się przebacza, nieuchronnie utrudni to zrozumienie faktu przebaczenia i przeżycie jego wartości ${ }^{15}$.

Zważywszy na fakt, iż umiejętność przebaczania nie jest wrodzona, spróbujmy pokazać, jak rozwija się ona u danego człowieka, odwołując się szczególnie do teorii relacji z obiektem, która wydaje się być odpowiednia do przedstawienia przydatnych wskazówek na ten temat, jak również do pokazania, gdzie i kiedy zaczynają się trudności, jakie napotykamy przy przebaczaniu.

Warto zwłaszcza zwrócić uwagę na istotne dwa uczucia przeszkadzające nam w procesie przebaczenia:

1) pierwsze uczucie to chęć zemsty, będącej satysfakcją z poczucia własnej mocy i godności. Myślimy wówczas: skoro ten drugi potrafił wyrządzić mi jakieś zło, to oznacza, że był on silniejszy ode mnie. Gdybym był takim,

13 Jerzy Popiełuszko, Homilia z dnia 26 grudnia 1982 r., http://xj.popieluszko.pl/xjp/ teksty-kazan/8450,26-grudnia-1982.html.

${ }^{14}$ Guardini, Bóg, 297.

15 Zob. Christian Duquoc, Casiano Floristán, „Il perdono”, Concilium 2 (1986): 2-28. 
jakim powinienem być, nie pozwoliłby sobie na to. Instynkt zemsty poprzez upokorzenie wroga pragnie przywrócić mi dobre samopoczucie. Poniżając tego drugiego, we własnych oczach wyrastam. Przebaczenie oznacza rezygnację z tej chęci. Wymaga ono, aby moje samopoczucie uniezależniło się od drugiego człowieka i aby wystarczyła mu świadomość nienaruszalnej wewnętrznej godności. Dzięki temu poczuję się pewniejszy, gdyż każda wolność odbiera doznanej obrazie jej ostrze i duchowo rozbraja nieprzyjaciela;

2) inne uczucie to pragnienie sprawiedliwości. Sprawiedliwość jest pewnym porządkiem, ustanawia ona właściwą relację nie między rzeczami i mocami, lecz miedzy osobami. Sprawiedliwość wymaga, aby każdy otrzymał to, do czego z racji swej istoty ma prawo. Oznacza ona właściwe relacje między osobami. Gdy ktoś wyrządza mi krzywdę, porządek ten ulega zakłóceniu - i to we mnie samym. Uczucie moje buntuje się przeciwko temu. Pragnienie sprawiedliwości wynika z obawy i pochodzi z najniższej sfery naszego życia. Sprawiedliwy porządek chroni człowieka. Może w tej sytuacji zaistnieć urażone poczucie własnej godności czy chęć zemsty, która zostaje zaspokojona, gdy jej narzędziem staje się sprawiedliwość. Nade wszystko chodzi tutaj o wolę otrzymania tego, co mi się należy ze względu na moją godność. Wyrazem najprostszym tego stanu rzeczy jest dawne prawo odwetu: „Oko za oko, ząb za ząb” (Wj 21, 24).

Zło, które mi ktoś wyrządził, winno spotkać również jego - odpłata za krzywdę i przekonanie o przywróceniu porządku. Przebaczenie oznaczałoby w tym kontekście rezygnację z pierwotnej formy domagania się sprawiedliwości czy osobistego wyegzekwowania kary. Jeśli „uregulowanie sprawy” powierzymy czynnikom postronnym: państwu, sądowi czy w ostatecznej instancji - Bogu, jest to już pewne oczyszczenie intencji.

Prawdziwie istotny krok stanowi dopiero jednak przebaczenie i to wówczas, gdy rezygnujemy z tego, by ów drugi człowiek w ogóle został ukarany. Od tego momentu wkraczamy w sferę wolności - opuszczamy sferę równoważnej odpłaty, gdzie za szkodę płaci się szkodą, za winę - pokutą. Zostaje przywrócony porządek i tutaj - ale już na wyższym poziomie - w wyniku twórczego przezwyciężenia. Poszerza się przestrzeń serca - z głębi serca wyrasta wspaniałomyślność i hojnie rozdarowujące się bogactwo - jakby ludzkie przeczucie tej Bożej mocy, którą nazywamy łaską. Przebaczenie przywraca porządek, „uniewinniając” tego drugiego i stwarzając mu nową szansę.

Wróćmy jeszcze do pytania, dlaczego mamy przebaczać? Dlaczego nie realizować sprawiedliwości? Czy właśnie sprawiedliwość nie jest czymś lepszym? Niektórzy odpowiadają, że przebaczenie jest bardziej ludzkie. Kto obstaje przy swoim prawie, stawia siebie ponad społecznością ludzką, czyni 
z siebie sędziego. A tymczasem jest się człowiekiem żyjącym wśród innych ludzi i wszystkich łączy wspólny los, dlatego trzeba przezwyciężać zatwardziałość serca i trzeba je poszerzać oraz „rozluźnić”.

Proces przebaczenia, jak nauczał Jan Paweł II, nie otrzyma żadnej szansy, jeżeli pojedynczy człowiek lub całe grupy nie zdobędą się uprzednio na uznanie swojej winy. Papież wymienił też pewne warunki do spełnienia, podobnie jak są określone warunki do spełnienia przez grzesznika, jeśli chce otrzymać przebaczenie od Boga, a są nimi: uznanie winy, skrucha, postanowienie poprawy, przyznanie się do winy i chęć zadośćuczynienia ${ }^{16}$.

By to rozumieć, potrzebny jest jednak pewien naturalny altruizm, pewna określona natura, pewna jakość. Jeśli znamy ludzi o takim usposobieniu, możemy też stwierdzić, że z tym usposobieniem mogą być związane też cechy negatywne: słabość, wydawanie siebie na pastwę innych, zamykanie oczu na sprawy, na które nie należy oczu zamykać, zdrada prawdy i prawa, a nawet nieobliczalne wybuchy mściwości i okrucieństwa. Inni znowu stwierdzają, że wola sprawiedliwości jest tak naprawdę niewolą. Kto natomiast przebacza, wyzwala się z zależności od krzywdy wyrządzonej mu przez drugiego. By to w pełni zrozumieć, konieczny jest pewien dystans do samego siebie i do drugiego człowieka. I ten medal ma drugą stronę - skłonność do lekceważenia w ogóle godności i praw osoby.

W akcie przebaczenia istnieje pewna szlachetność - wartość, jaką budzi i reprezentuje wspaniałomyślne usposobienie, ale Nowy Testament idzie jeszcze dalej. Chrystus nie opiera swego napomnienia na motywach społecznych czy etycznych, czy wewnątrzświatowych, lecz łączy przebaczenie człowieka z tym, którego udziela Bóg. To Bóg jest pierwszym i rzeczywistym Przebaczającym, a człowiek jest Bożym dzieckiem. A zatem przebaczenie ma swoje źródło w Ojcu niebieskim.

Niech nam zatem przebaczy Bóg, jak my pragniemy przebaczyć tym, którzy nam wyrządzili krzywdę. Jeśli przygotowujesz się do modlitwy i tam wspomnisz, że masz coś przeciwko twojemu bliźniemu, przebacz mu. Inaczej to, czego nie przebaczyłeś, wejdzie między ciebie i Ojca i uczyni Go głuchym na twoją prośbę. Boże przebaczenie jest łaską, a nie czymś zasłużonym.

Tekst w Ewangelii Mateusza (Mt 18, 15) idzie jeszcze dalej: „Gdy brat twój zgrzeszy przeciwko tobie, idź i upomnij go... Jeśli cię usłucha, pozy-

16 Zob. Jan Orzeszyna, „Jan Paweł II. Pojednanie z Bogiem i pojednanie między ludźmi”, w: Wielka Encyklopedia Nauczania Jana Pawta II (Radom: Polskie Wydawnictwo Encyklopedyczne, 2014), 11. 
skasz swego brata". Zauważmy, że ten, który zgrzeszył, nie pragnie przebaczenia, ale jest zatwardziały w złu. Zresztą największą urazę do człowieka żywi ten, kto wobec niego w czymś zawinił. Jeśli zatem odkryjesz, że ktoś zawinił wobec ciebie, nie powinieneś pozwolić, by powstała w tobie zawziętość - idź sam do niego i staraj się uświadomić mu, że popełnił zło, aby nastąpić mogło przebaczenie. Przebaczenie jest zatem częścią czegoś szerszego - miłości. Miłość zaś, jak pisze Annalisa Giulianini, przyjmuje kształt przebaczenia, gdy doznaje krzywdy ${ }^{17}$.

Powinniśmy przebaczać, ponieważ powinniśmy kochać. Dlatego przebaczenie jest aktem tak bardzo wolnym. Wypływa ono z wnętrza człowieka, ze współuczestnictwa w Bożym przebaczeniu. Ma ono charakter stwórczy. Człowiek przebaczający - jak również ten, kto miłuje nieprzyjaciela, jest podobny do Ojca, który sprawia, ,że słońce Jego wschodzi nad złymi i dobrymi, i zsyła deszcz na sprawiedliwych i niesprawiedliwych" (Mt 5, 45). Jeśli tak uczynisz, pozwolisz bliźniemu zrozumieć, że wyrządził krzywdę, przebaczysz mu i ,pozyskasz swego brata”. Stosunek braterstwa zostanie przywrócony, drugi człowiek dla myślącego w ten sposób staje się kimś cennym. Uświadamia sobie, że dopuścił się zła, boli go, podobnie jak boli Boga, kiedy człowiek przez grzech od Niego odpada. Człowiek tak działający pragnie, by jego bliźni, który go skrzywdził, uznał popełnione przez siebie zło i przez to powrócił do wspólnoty ${ }^{18}$.

Przykład takiego przebaczenia daje nam Chrystus wobec naśmiewających się z Niego i Go krzywdzących - „Ojcze przebacz im” (Łk 23, 24). Jest całkowicie wolny. Wyniósł On sprawiedliwość na niewypowiedzianie wyższy poziom łaski.

Przebaczenie Boga nie dokonało się zatem jako samo tylko przebaczenie, lecz jako zadośćuczynienie. Nie wymazał On winy, ale przywrócił rzeczywistą "sprawiedliwość" - otwierając naszą perspektywę życia ku zbawieniu.

\section{4. Środowiska wychowania do wartości przebaczenia}

Gdzie i kto powinien wychowywać do przebaczenia? Na tak sformułowane pytanie odpowiada się najczęściej, odnosząc się do rodziny. Zadaniem

17 Zob. Annalisa Giulianini, O przebaczeniu, czyli jak uleczyć duszę (Kraków: Wydawnictwo Bratni Zew, 2010), 48.

18 Tamże, $48 \mathrm{n}$. 
rodziny jest i powinno stawać się wychowanie stawiające na rozwój emocjonalny - w uruchomieniu tego, co określamy symbolicznie sercem. Następnie widzimy potrzebę uwzględnienia w tej pracy także szkoły oraz innych instytucji edukacyjnych, w których realizowane jest nauczanie i wychowanie w ramach wprowadzania w etos społeczny w jak najszerszym sensie ${ }^{19}$.

Wychowanie moralne, często odwołując się do psychologii kognitywnej i genetyki (L. Kohlberg), poza aspektem sprawiedliwości odnosi się także do miłosierdzia i przebaczenia, które w przeciwieństwie do sprawiedliwości, nie wymagają wzajemności ${ }^{20}$.

W takim też znaczeniu właściwie uformowana świadomość moralna wnosi coś więcej niż tylko rozwój osądu moralnego, jak to postuluje psychologia kognitywna. Wskazuje się też, że o wiele bardziej niż przez uczenie się i opanowywanie określonej wiedzy, następuje interioryzacja przebaczenia, jako zasady moralności i wartości, przez identyfikację z osobami rzeczywistymi lub literackimi czy bohaterami historycznymi, które przejawiały tego rodzaju postawy przebaczenia. Już powyżej przywołane przykłady z literatury (z dzieł Henryka Sienkiewicza), jak też z nauczania Chrystusa wskazują, że człowiek religijny, chrześcijanin, będzie skłonny do realizowania przebaczenia w swoim życiu na tyle, na ile doświadczył dobroci Boga w odniesieniu do siebie samego ${ }^{21}$.

Konkretne modele pokazywane przez tak zwane „osoby znaczące” z naszego otoczenia: rodziców, wychowawców i nauczycieli, animatorów, ale też postaci symboliczne i ideały wychowawcze, powinny ukazywać wartość przebaczenia w jego specyficznych kontekstach, jak też w konkretnych postawach. Należałoby także na płaszczyźnie teoretycznej dokonywać przedstawiania i opracowywania znaczenia i wartości przebaczenia z ukazywaniem też argumentów za i przeciw tej wartości. Również programy wychowawcze, dydaktyczne i katechetyczne powinny stanowić istotny element promocji wartości przebaczenia i wspomagania rozwoju zdolności przebaczenia ${ }^{22}$.

W tych wszystkich środowiskach niezbędne jest dążenie do przeżywania pojednania, jako rzeczywistości ich codziennego życia z obecnością ta-

19 Robert D. Enright, Elisabeth A. Gassin, Ching-Ru Wu, „Forgiveness: a developmental view", Journal of Moral Education 2 (1992): 99-114.

${ }^{20}$ Zob. Le sacrement du pardon entre hier et demain, red. Louis-Marie Chauvet, Paul De Clerck (Paris: Desclé, 1993); także Jean Lambert i in., Pardonner (Bruxelles: Facultés Universitaires Saint-Louis, 1994).

21 Zob. Schepens, „Perdono”, 813.

22 Zob. tamże. 
kich postaw, jak: zdolność uznania winy, skrucha, postanowienie poprawy, chęć zadośćuczynienia.

Jan Paweł II podkreślał w odniesieniu także do tego środowiska wychowawczego, jakim jest Kościół, że jeśli chce on wychowywać do tej wartości, winien sam stawać się Kościołem pojednanym, a zatem wspólnotą uczniów Chrystusa zjednoczonych obowiązkiem stałego nawracania się do Boga i starających się żyć życiem godnym nowych ludzi. Stąd wszyscy członkowie Kościoła winni pracować nad uspokojeniem swoich umysłów, redukowaniem napięć, przezwyciężaniem podziałów, uzdrawianiem ran, jakie powstają w sytuacjach różnic stanowisk i dyskusji, jednocześnie szukając jedności w tym, co stanowi podstawę wiary i życia chrześcijańskiego, kierując się znaną ze starożytności chrześcijańskiej zasadą: „W sprawach wątpliwych wolność, w koniecznych jedność, we wszystkim miłość" (In dubiis libertas, in necessariis unitas, in omnibus caritas) (por. ReP 9) ${ }^{23}$.

Pomocą w organizacji takiego środowiska wychowawczego i tworzeniu odpowiedniej w nim atmosfery do tego rodzaju pracy wychowawczej mogą być słowa Jana Pawła II, zwracającego uwagę także na związek, jaki zachodzi pomiędzy pojednaniem człowieka z Bogiem a odnową życia społecznego. W tym związku upatrywał Jan Paweł II podstawową przesłankę i pewny fundament każdej trwałej odnowy społecznej i pokoju między narodami ${ }^{24}$.

Idąc tą drogą, Kościół przemienia dziejową sytuację nienawiści i przemocy w cywilizację miłości. Świat współczesny, jak o tym była mowa na początku artykułu, tęskni za przebaczeniem i lepszą rzeczywistością - jest to widziane zresztą jako znamienna cecha czasów współczesnych. Dzisiaj, jak zresztą chyba od zawsze, na świecie bardzo potrzeba przebaczenia, które nie dotyczy tylko sytuacji czy wydarzeń wyjątkowych, lecz także drobnych spraw życia codziennego, które nie oszczędzają nikomu rozczarowań i zawodów w kontaktach z innymi. Wybaczenie opiera się bowiem na niezbitym fakcie obiektywnym, to znaczy errare humanum est, a zatem dopuszczenie możliwości popełnienia błędu oznacza dopuszczenie konieczności, aby przebaczyć i dostąpić przebaczenia ${ }^{25}$. Jednak, zdaniem Jana Pawła II, ta tę-

23 Jan Paweł II, Adhortacja apostolska Reconciliatio et paenitentia (Roma: Libreria Editrice Vaticana, 1984).

${ }^{24}$ Jan Paweł II, Przemówienie Pojednanie chrześcijańskie i ludzka wspólnota, Loreto, 11.04. 1985.

${ }^{25}$ Por. Giulianini, O przebaczeniu, 66. 
sknota może zostać spełniona na tyle, na ile współczesny świat zdoła sam uleczyć się z grzechu (ReP 3$)^{26}$.

\section{Forgiveness in Education (Summary)}

Forgiveness is the essential problem of human life and education, which came into existence together with Christianity. This is the most human fact, proving the size of human nature, also perceived as the symptom of weakness and the lack of courage. The formulations of forgiveness are discussed in the light of psychological, social, environmental, or sometimes also philosophical, and mostly theological aspects. The article, starting from the description of the fact of forgiveness and its etymological and anthropological interpretation, shows the shape of the man who is naturally condemned to the possibility of making mistakes and the necessity of forgiveness as the value to which one should and can be educated on. Places and the environment of education are, above all, the family, then school and different educational institutions, and also the Church - as the community of believers.

The properly formed moral consciousness requires learning and mastering specific knowledge, internalization of forgiveness as a principle of morality and as a value, through identification with real or literary persons, or the historical heroes who manifest this kind of attitude of forgiveness.

Educational, didactic and catechistic programmes should make up the essential element of the promotion of the value of forgiveness and the aid of the human development. The indispensable endeavor is to experience the reconciliation in these environments, as realities of everyday life with the presence of such attitudes as: the ability of the acknowledgement of the fault, repentance, the decision of the improvement, the desire of the fulfilment. In relation to the Church as the educational environment promoting forgiveness it has been shown that it should first become the reconciled Church thus the community of Christ's pupils united with the duty of continuous conversion to God and efforts to live a life worthy of the new people. All members of the Church should work on calming their minds, reducing tensions, overcoming divisions, healing the wounds which appear when there are differences of positions and discussion, acting according to the well-known from the Christian antiquity principle: "Liberty in doubtful things, unity in necessary thins, charity in

${ }^{26}$ Zob. Jan Orzeszyna, „Pojednanie”, w: Jan Pawet II. Encyklopedia Nauczania Moralnego, red. Janusz Nagórny, Krzysztof Jeżyna (Radom: Polskie Wydawnictwo Encyklopedyczne, 2005), 393-396. 
all things" (In dubiis libertas, in necessariis unitas, in the omnibus caritas). The educational environment of the Church transforms the historical situation of hatred and violence in the civilization of love. The present world, missing forgiveness and better reality, admits the possibility of making mistakes, simultaneously, perceiving the necessity of forgiveness and the experiencing it in life.

Key words: forgiveness; reconciliation; compassion; value; education.

\section{Przebaczenie w wychowaniu (Streszczenie)}

Przebaczenie jest istotnym problemem życia i wychowania człowieka, który pojawił się wraz z nadejściem chrześcijaństwa. Jest to fakt najbardziej ludzki, świadczący o wielkości człowieczeństwa, ale postrzegany także jako przejaw słabości i braku odwagi. Ujęcia przebaczenia naświetlane są aspektami psychologicznymi, społecznymi czy środowiskowymi, czasami także filozoficznymi, a zwłaszcza teologicznymi. W artykule, wychodząc od opisania faktu przebaczenia i jego etymologicznej oraz antropologicznej interpretacji, wskazuje się na kondycję człowieka, która zgodnie z naturą, jest skazana na możliwość popełnienia błędu i konieczność przebaczenia jako wartość, do której należy i można wychowywać. Miejsca i środowiska wychowania to nade wszystko rodzina, następnie szkoła czy inne instytucje edukacyjne, jak również Kościół jako społeczność wierzących.

Właściwie uformowana świadomość moralna wymaga uczenia się i opanowywania określonej wiedzy, interioryzacji przebaczenia jako zasady moralności i jako wartości, przez identyfikację z osobami rzeczywistymi lub literackimi czy bohaterami historycznymi, które przejawiają tego rodzaju postawy przebaczenia.

Programy wychowawcze, dydaktyczne i katechetyczne powinny stanowić istotny element promocji wartości przebaczenia i wspomagania rozwoju człowieka. W tych wszystkich środowiskach niezbędne jest dążenie do przeżywania pojednania, jako rzeczywistości codziennego życia, z obecnością takich postaw, jak: zdolność uznania winy, skrucha, postanowienie poprawy, chęć zadośćuczynienia. W odniesieniu do Kościoła, jako środowiska wychowania do przebaczenia, wskazuje się, że powinien on najpierw sam stawać się „Kościołem pojednanym”, a zatem wspólnotą uczniów Chrystusa zjednoczonych obowiązkiem stałego nawracania się do Boga i starających się żyć życiem godnym nowych ludzi. Wszyscy członkowie Kościoła winni pracować nad uspokojeniem swoich umysłów, redukowaniem napięć, przezwyciężaniem podziałów, uzdrawianiem ran, jakie powstają w sytuacjach różnic stanowisk i dyskusji, kierując się znaną ze starożytności chrześcijańskiej zasadą: „W sprawach wątpliwych wolność, w koniecznych jedność, we wszystkim 
miłość" (In dubiis libertas, in necessariis unitas, in omnibus caritas). Środowisko wychowawcze, jakim jest Kościół, przemienia dziejową sytuację nienawiści i przemocy w cywilizację miłości. Świat współczesny, tęskniąc za przebaczeniem i lepszą rzeczywistością, dopuszcza możliwość popełnienia błędu, a zarazem dostrzega konieczność przebaczenia i doświadczania go w życiu.

Stowa kluczowe: przebaczenie; pojednanie; współczucie; wartość; wychowanie.

\section{Bibliografia}

Duquoc, Christian, Casiano Floristán. „Il perdono”. Concilium 2 (1986): 2-28.

Enright, Robert D., Elisabeth A. Gassin, Ching-Ru Wu. „Forgiveness: a developmental view". Journal of Moral Education 2 (1992): 99-114.

Franciszek. Mitosierdzie to imię Boga. Kraków: Znak, 2015.

Giulianini, Annalisa. O przebaczeniu, czyli jak uleczyć duszę. Kraków: Wydawnictwo Bratni Zew, 2010.

Guardini, Romano. Bóg. Nasz Pan Jezus Chrystus - Osoba i życie, thum. Juliusz Zychowicz. Warszawa: Apostolicum, 1999.

Jan Paweł II, Przemówienie Pojednanie chrześcijańskie i ludzka wspólnota. Loreto, 11.04.1985.

Jan Paweł II. Adhortacja apostolska Reconciliatio et paenitentia. Roma: Libreria Editrice Vaticana, 1984.

Lambert, Jean i in. Pardonner. Bruxelles: Facultés Universitaires Saint-Louis, 1994. Le sacrement du pardon entre hier et demain, red. Louis-Marie Chauvet, Paul De Clerck. Paris: Desclé, 1993.

Mały stownik języka polskiego, red. Stanisław Skorupka, Halina Auderska, Zofia Łempicka. Warszawa: PWN, 1969.

Marcel, Gabriel. Homo viator. Roma: Borla, 1980.

Maryniarczyk, Andrzej. „Homo Viator”. Człowiek w Kulturze 23 (2013): 29-35.

Nanni, Carlo. Educare cristianamente. Lettere spirituali a educatori, insegnanti e formatori. Leumann-Torino: Elledici, 2005.

Orzeszyna, Jan. „Jan Paweł II. Pojednanie z Bogiem i pojednanie między ludźmi”. W: Wielka Encyklopedia Nauczania Jana Pawła II, 11-16. Radom: Polskie Wydawnictwo Encyklopedyczne, 2014.

Orzeszyna, Jan. „Pojednanie”. W: Jan Pawet II. Encyklopedia Nauczania Moralnego, red. Janusz Nagórny, Krzysztof Jeżyna, 393-396. Radom: Polskie Wydawnictwo Encyklopedyczne, 2005. 
Popiełuszko, Jerzy. Homilia z dnia 26 grudnia 1982 r. http://xj.popieluszko.pl/xjp/ teksty-kazan/8450,26-grudnia-1982.html.

Schepens, Jacques. „Perdono”. W: Dizionario di scienze dell'educazione, red. José M. Prellezo, Guglielmo Malizia, Carlo Nanni, 812-813. Torino: ElleDiCi SEI, 1997.

Sienkiewicz, Henryk. Quo vadis. Warszawa: PIW, 1961. 